Thi-Qar Medical Journal (TQMJ): Vol.(19), No.(1), 2020

Web Site: https://jmed.utq.edu.iq

Email:utjmed@utq.edu.iq

ISSN (Print):1992-92 18, ISSN (Online):1992-92 18

DOI: https://doi.org/10.32792/utq/utjmed/19/1/10

\title{
Evaluation Of Serum 1,5 - Anhydroglucitol Levels among Type 2 Diabetic Patients in Basrah
}

\author{
Safa K.Qasim ${ }^{1}$, B.Sc. \\ Salman K.Ajlan', MBChB, MSc, MRCP (Endocrinology \& Diabetes, UK), \\ E-mail: salman.ajlan@uobasrah.edu.iq
}

\begin{abstract}
Objective: To determine serum 1,5- anhydroglucitol (1,5-AG) levels among patients with type 2 diabetes (T2D) in Basrah, and to evaluate the changes in 1,5-AG levels with regard to the status of glycaemic control.

Methods: The present study included 76 patients with T2D, 33 males and 43 females, 30-78 years of age. Height, weight, waist circumference, systolic blood pressure, and diastolic blood pressure were measured. Fasting blood glucose (FBG), glycated haemoglobin (HbA1c) and serum 1,5-AG levels were determined.
\end{abstract}

Results: The study revealed that T2D patients have low serum 1,5-AG concentrations $(3.62 \pm 1.56) \mu \mathrm{g} / \mathrm{ml}$. The comparative male and female values were $(3.69 \pm 1.55) \mu \mathrm{g} / \mathrm{ml}$ and $(3.57 \pm 1.58) \mu \mathrm{g} / \mathrm{ml}$. The vast majority of the included diabetic patients $(90.8 \%)$ were in a state of poor glycemic control, with $6.6 \%$ have an suboptimal metabolic control. On the other hand, good glycemic was documented in $2.6 \%$ of patients. There were no significant differences in plasma 1,5-AG concentrations with regard to the status of glycaemic control $(P>0.05)$.

Conclusion: T2D patients have reduced serum 1,5-AG concentrations. Thus, it could be, potentially, valuable test for the diagnosis of diabetes mellitus. Diabetic patients were in poor glycaemic state. Therefore, they are at a substantial risk for the development of diverse diabetic complications.

Key words: Diabetes mellitus, 1,5-AG level, glycaemic control.

Evaluation of Serum 1,5-Anhydroglucitol levels Among Type 2 Diabetic Patients in Basrah Assist. Professor*

${ }^{1}$ College of Pharmacy.

${ }^{2}$ Department of Biochemistry, College of Medicine, University of Basrah, Basrah, IRAQ.

*: To whom correspondence should be sent 
Thi-Qar Medical Journal (TQMJ): Vol.(19), No.(1), 2020

Web Site: https://jmed.utq.edu.iq

Email:utjmed@utq.edu.iq

\section{ISSN (Print):1992-92 18, ISSN (Online):1992-92 18 \\ DOI: https://doi.org/10.32792/utq/utjmed/19/1/10}

\section{Introduction:}

In the $21^{\text {st }}$ century, Diabetes mellitus ( $\mathrm{DM})$ is regarded as the most known noncommunicable disease over the globe, occupying the $4^{\text {th }}$ to $5^{\text {th }}$ rank among death causing diseases in developed countries. ${ }^{1}$ Diabetes prevalence had been studied in many countries over the world for adult over 20 years in 1995, the outcome of this study manifest that the prevalence of DM in this year scored $4 \%$ which equal to 135 million people. The same study also predict a rising in the prevalence to $5.4 \%$ by the year of 2025 which is equal to 300 million people. This increment is especially occur in India, China, and US. ${ }^{2}$ India showed the maximum increases in the last few years with 31.7 million. The prevalence of DM in rural population is one quarter that of urban population, and by this it will have the largest number of diabetic people all over the world. ${ }^{3}$

One, five-anhydroglucitol (1,5-AG) is a major polyol in the human serum. ${ }^{4}$

It is naturally occurring monosaccharide structurally similar to the D-glucose with an exception for the first position hydroxyl group which is reduced in 1,5-AG. ${ }^{5}$ There is a suggestion that serum level of $1,5-\mathrm{AG}$ reflects glycemic control, and also it is changes sensitively to the alteration in plasma glucose level. In addition, it can act as mirror for postprandial hyperglycemia. ${ }^{4}$

In healthy individuals, the reference value of serum 1,5-AG ranging from $12-40 \mu \mathrm{g} / \mathrm{ml}$ and its half-life lasting for 1-2 weeks. ${ }^{6,7}$ The concentration of $1,5-\mathrm{AG}$ among diabetic patients may vary from 0.9 to 26.6 $\mu \mathrm{g} / \mathrm{ml}^{8}{ }^{8}$ The degree of the reduction in the $1,5-\mathrm{AG}$ serum level is directly proportional to the glycosuria severity. ${ }^{8,9}$ When the normal serum level of glucose has been restored, the 1,5-AG increased again showing reversible relationship with the glycemic control recovery. ${ }^{10,11}$

As 1,5-AG level show high stability in euglycaemic persons and doesn't affected by age, gender, and prandial state. ${ }^{12,13}$ Therefore, it is regarded as a sensitive marker for short term glycemic control as it reflect the glycemic control over a period ranging from two days to two weeks among diabetic patients. ${ }^{14}$ However, other studies reported that 1,5-AG reflect glucose excursions from 1-3 days to some weeks. ${ }^{15}$ These observations make it a powerful predictor for postprandial hyperglycemia, so occupying a plausible helpful role in glycemic control assessment. ${ }^{16,17}$

The aims of this study were to estimate serum 1,5-AG levels among patients with type 2 diabetes (T2D) in Basrah, and to investigate the changes in 1,5-AG levels with regard to the status of glycaemic control.

\section{Patients and Methods:}

This is cross-sectional study conducted from November, 2017 throughout March 2018 and included 76 patients with T2D consulted Endocrinology and Diabetic Center in Al-Mawane General Hospital, Basrah, Southern of Iraq. They were 33 males and 43 females, $30-78$ years of age. These patients were diagnosed by Consultant Physicains.

The information were obtained from each participant through an already prepared questionnaire form. The questionnaire was based on socio-demographic characteristics that include, age, gender, residency, educational level, smoking habits, and alcohol consumption. Regarding diabetic information, patients were enquired about 
Thi-Qar Medical Journal (TQMJ): Vol.(19), No.(1), 2020

Web Site: https://jmed.utq.edu.iq

Email:utjmed@utq.edu.iq

\section{ISSN (Print):1992-92 18, ISSN (Online):1992-92 18 \\ DOI: https://doi.org/10.32792/utq/utjmed/19/1/10}

diabetes type, duration, current treatment whether insulin or oral antihyperglycaemic agents (OHA), and also the presence of diabetic complications, other systemic diseases and other types of treatment.

Physiological measurements were performed including systolic (SBP) and diastolic (DBP) blood pressure, weight and height for the estimation of body mass index (BMI), and waist circumference (WC).

Fasting blood glucose (FBG) was determined using enzymatic kit (GLUCPAP) from RANDOX Laboratories, United kingdom. Estimation of $\mathrm{Hb} \mathrm{A} 1 \mathrm{c}$ level was preformed by ion - exchange high-performance liquid chromatography (HPLC) using the VARIANT ${ }^{\mathrm{TM}}$ program form BIO-RAD. USA. Measurement of serum 1,5-AG level was done by using enzyme linked immunosorbent assay method (ELISA) using kit provided by $\mathrm{My}$ Biosource, USA

Data were analyzed in the computer by using SPSS "Statistical Package For Social Sciences Program" Version 23. The results are expressed as [mean $+\mathrm{SD}$, range, percentage]. $\mathrm{P}$ value $<0.05$ was considered the lowest limit for significance.

\section{Results:}

Table 1 presents to socio-demographic characteristics of diabetic patients. Most patients (75\%) were between 45 and 64 years of age. The frequency of patient living in urban areas was distinctly greater than those living in rural areas with comparative figures of $72.4 \% 27.6 \%$. With regard to the educational level, $52.6 \%$ of patients completed primary school with only $2.6 \%$ just read and write. The vast majority of patients were nonsmokers $82.9 \%$, while current smokers and ex-smoker represented $13.2 \%$ and $3.9 \%$ respectively.

Clinical characteristics of the studied patients are described in Table 2. The mean levels of the SBP and DBP among males were $134.7 \pm 23.2$ and $84.4 \pm 7.8$ $\mathrm{mm} . \mathrm{Hg}$ respectively. Among females, the comparative frequencies were $136.7 \pm 19.4$ and $86.1 \pm 9.0 \mathrm{~mm} . \mathrm{Hg}$. Concerning BMI categories, overweight and grade I obesity were observed in $34.2 \%$ and $36.8 \%$ of diabetic patients respectively, while grade III obesity was recorded only in $3.9 \%$ of patients. On the other hand, most males have central obesity with $\mathrm{WC} \geq 102 \mathrm{~cm}$ and a mean of $104.9 \pm 13.4 \mathrm{~cm}$. Also, the vast majority of females have $\mathrm{WC} \geq 88 \mathrm{~cm}$ with a mean of $107.2 \pm 15.1 \mathrm{~cm}$.

Nearly half of patients (48.6\%) have diabetes duration from 5-15 years, 28.9\% with duration less than 5 years and only $22.4 \%$ with duration of more than 15 years. Regarding treatment modalities, the studied diabetic patients showed approximately equal frequencies of type of therapy, where $35.5 \%$ treated by OHA, $31.6 \%$ by insulin and $32.9 \%$ by both modalities.

Table 3 demonstrated the measured biochemical parameters. The mean value of FBG was $235.33 \pm 81.14 \mathrm{mg} / \mathrm{dl}$. The overall mean of $\mathrm{HbA} 1 \mathrm{c}$ was $10.47 \pm$ $1.96 \%$. The highest proportion of patients (90.8\%) have poor glycemic control (HbAlc $\geq 8 \%$ ). Regarding serum 1,5-AG concentrations among diabetic patients, the reported value was $3.62 \pm 1.56 \mu \mathrm{g} / \mathrm{ml}$. The male and female figure were $3.69 \pm 1.55$ and $3.57 \pm 1.58 \mu \mathrm{g} / \mathrm{ml}$ respectively. 
Thi-Qar Medical Journal (TQMJ): Vol.(19), No.(1), 2020

Web Site: https://jmed.utq.edu.iq

Email:utjmed@utq.edu.iq

\begin{abstract}
ISSN (Print):1992-92 18, ISSN (Online):1992-92 18
DOI: https://doi.org/10.32792/utq/utjmed/19/1/10
\end{abstract}

As presented in Table 4, there were no significant differences in serum 1,5-AG

\section{Discussion:}

$\mathrm{DM}$ is considered as a universal health problem that may occur at any age. ${ }^{18}$

The prevalence of DM shows growing burden within the short future. ${ }^{19}$ In addition to the broad spectrum of complications frequently encountered in this syndrome. ${ }^{20}$ These clinical consequences may appear even in prediabetic stage among those with impaired fasting glucose (IFG) and impaired glucose tolerance (IGT). ${ }^{21-25}$ Thus an imperative need have been arisen for more intensive and sensitive marker that's not only predict the blood glucose level but also revealed a recent hyperglycemic excursions. $^{26}$

Unfortunately the vast majority of our diabetic patients where in poor glycemic status, where, $90.8 \%$ of the included patients have $\mathrm{HbAlc} \geq 8 \%$. This state of poor metabolic control implies that these patients at a considerable risk of macro- as well as micro- vascular complications. ${ }^{27,28}$ This finding is comparable to the observation of other workers. ${ }^{29-31}$ In addition, several studies conducted earlier in Basrah revealed that the vast majority of diabetic patients have had distinctly hyperglycemic FBG values. Also, they were in a poor metabolic status reflected by the presence of considerably high $\mathrm{HbA} 1 \mathrm{c}$ figures. $^{32-36}$ Furthermore, it has been reported that the frequency of metabolic syndrome among diabetic patients in Basrah was considerably high. ${ }^{37}$ This imposed a further increment in cardiovascular disease risk among our concentrations among the studied patients with regard to the status of metabolic control $(\mathrm{P}>0.05)$.

diabetic patients putting them at a substantial risk for the development of cardiovascular events.

This study obviously illustrated that diabetic patients have distinctly reduced serum 1,5-AG concentrations. This finding is consistent with the results of low serum 1,5-AG level reported by several workers. $^{10,13,16,17,26,38-43}$ The present study demonstrated that the majority of the included patients showed profound hyperglycaemia as indicated by the distinctly high FBS. This fact of marked hyperglycaemia resulted in the reduction of the 1,5-AG level in blood among these patients. The reduction was attributed to the competition mechanism occurs between glucose and 1,5-AG on the reabsorption site in the proximal renal tubules. ${ }^{43,44}$ During hyperglycaemic episode, when the glucose excretion overwhelm its reabsorption, sodium glucose active cotransporter 4 (GLUT 4) system participated in the reabsorption process. This system for unknown reasons would favor glucose reabsorption rather than $1,5-\mathrm{AG}$, leading to a decrease 1,5-AG reabsorption, and hence plasma 1,5-AG level is consequently reduced. $^{44}$

Low plasma level of 1,5-AG among patients with T2D is associated with several advantages in clinical setting. Firstly, it can be valuable tool for screening of diabetes among subjects with high probability of DM. ${ }^{45}$ It has been proposed that plasma 1,5-AG could be used as useful marker for DM screening especially when 
Thi-Qar Medical Journal (TQMJ): Vol.(19), No.(1), 2020

Web Site: https://jmed.utq.edu.iq

Email:utjmed@utq.edu.iq

\section{ISSN (Print):1992-92 18, ISSN (Online):1992-92 18 \\ DOI: https://doi.org/10.32792/utq/utjmed/19/1/10}

combined with FBG. ${ }^{46}$ Secondly, measuring plasma level of 1,5-AG may be helpful in the confirmation of the DM diagnosis among symptomatic individuals were the demonstration of low level is sufficient for the diagnosis. Several workers emphasize on the diagnostic significance of plasma 1,5-AG determination in the confirmation of the presence of DM..$^{45,47}$ These two points, definitely required the removal of the current overlap existing in the lower part of the normal range of blood level of 1,5-AG with the diabetic range, and also the establishment of clear-cut value to differentiate between normal and abnormal 1,5-AG blood values.

The third point regarding the utility of measuring the level of blood 1,5-AG concentration, is that it may be particularly helpful in the assessment of the status of metabolic control among diabetic patients especially if serial determinations of serum 1,5-AG levels are performed in order to follow the changes in 1,5-AG homeostasis. This is of paramount importance during the period of hyperglycemic crisis or post prandial glycemic excursions. Several workers proposed that plasma 1,5-AG estimation may be particularly helpful in the assessment of the glycemic control among patients with DM. ${ }^{48-51}$

The present study revealed no significant differences in serum 1,5-AG levels with regard to $\mathrm{HbA} 1 \mathrm{c}$. There is a wide area of controversy with regard to the pattern of association between $\mathrm{HbAlc}$ and blood levels of 1,5-AG. On one hand, some studies showed contradictory findings in comparison to the present study. These emphasized that plasma 1,5-AG reflect the glycemic excursion and post prandial hyperglycemia more sensitively and robustly in patients with good glycemic control when $\mathrm{HbAlc}$ figures are $8 \%$ and below. ${ }^{9,17,50,52}$ Thus in patients with well to moderately glycemic control, $1,5-\mathrm{AG}$ could be regarded as useful indicator of daily glycaemic excursions as well as an ancillary and even better marker than HbAlc in the evaluation of the deteriorating glycemic control. ${ }^{26}$

On the other hand, other workers demonstrated different results. They illustrated that 1,5-AG level in the blood wasn't better than $\mathrm{HbAlc}$ as predictor for hyperglycemia. ${ }^{53}$ In addition, several other reports also illustrated no relationship between 1,5-AG and HbAlc. ${ }^{54,55}$ This is in contrast with other studies that revealed that 1,5-AG show high specificity and sensitivity to even tiny glycemic excursions, even with slight increment in HbA1c. ${ }^{10,42,43}$

We conclude that T2D patients have distinctly low serum 1,5-AG levels. This implies that measurement of serum 1,5-AG concentration could be a potential candidate as a diagnostic test for diabetes. Diabetic patients were obviously in poor glycaemic state. Thus, they are considerably at more risk for the occurrence and progression of diabetic complications. 
Thi-Qar Medical Journal (TQMJ): Vol.(19), No.(1), 2020

Web Site: https://jmed.utq.edu.iq

Email:utjmed@utq.edu.iq

\section{ISSN (Print):1992-92 18, ISSN (Online):1992-92 18 \\ DOI: https://doi.org/10.32792/utq/utjmed/19/1/10}

\section{References:}

1. Amos A, McCarry D, Zimmet P. The rising global burden of diabetes and its complications: estimates and projections to the year 2010.Diabetic Medicine 1987; 14: S1-S85.

2. King H, Aubert R, HermanW. Global Burden of Diabetes, 1995-2025: Prevalence, numerical estimates, and projections. Diabetes Care 1998; 21:1414-1431.

3. Kaveeshwar S, Cornwall J. The current state of diabetes mellitus in india. Australasian Medical Journal 2014; 7: 45-48.

4. Koga M, MuraiJ, Saito H, Mukai M, Kasayama S, et al. Habitual intake of dairy products influences serum 1,5- anhydroglucitol levels independently of plasma glucose. Diabetes Research and Clinical Practice 2010; 90: 122-125.

5. Kilpatrick ES, Keevilt BG, Richmond KL, Newland P, Addison GM, et al. Plasma 1,5anhydroglucitol concentrations are influenced by variations in the renal threshold for glucose. Diabetic Medicine 1999; 16: 496-499.

6. Januszewski AS, Karschimku C, Davis KER, O,Neal D, Ward G, Jenkins AJ, et al. Plasma 1,5-anhydroglucitol levels, a measure of short term glycaemia: Assay assessment and lower levels in diabetic vs. non-diabetic subjects. Diabetes Research and Clinical Practice 2012; 95: e17-e19.

7. Yamanouchi T, Akanuma Y, Toyota T, Kuzuya T, Kawai T, Kawazu S, et al. Comparison of 1,5-anhydroglucitol, HbA1c, and Fructosamine for Detection of Diabetes Mellitus. Diabetes 1991; 40: 52-57.

8. Dworacka M, Wender-Ozegowska E, Winiarska H, Borowska M, Zawiejska A, Pietryga M, et al. Plasma anhydro-D-glucitol (1,5-AG ) as an indicator of hyperglycaemia excursions in pregnant women with diabetes. Diabetic Medicine 2006; 23: 171-175.

9. Won JC, Park CY, Park HS, et al. 1,5-anhydro-D-glucitolreflects post prandial hyperglycemia and a decreased insulinogenic index, even in subjects with prediabetes and well-controlled type 2 diabetes. Diabetes Research and Clinical Practice 2009; 84: 51-57.

10. McGill JB, Cole TG, Nowatzke W, Houghton S, Ammirati EB, GautilleT, et al. U.S. trail of the GlycoMark assay: Circulating 1,5-anhydroglucitol levels in adult patients with diabetes reflect longitudinal changes of glycemia: a U.S. trial of the GlycoMark assay. Diabetes Care 2004; 27: 1859-1865. 
Thi-Qar Medical Journal (TQMJ): Vol.(19), No.(1), 2020

Web Site: https://jmed.utq.edu.iq

Email:utjmed@utq.edu.iq

ISSN (Print):1992-92 18, ISSN (Online):1992-92 18

DOI: https://doi.org/10.32792/utq/utjmed/19/1/10

11. Stickle D, Turk J. A kinetic mass balance model for 1,5-anhydroglucitol: applications to monitoring of glycemic control. American Journal of Physiology 1997; 273: E821-E830.

12. Onorato JM, Langish RA, Shipkova PA, Sanders M, Wang J, Kwagh J, et al.

A novel method for the determination of 1,5-anhydroglucitol, a glycemic marker, in human urine utilizing hydrophilic interaction liquid chromatography/ MS3. Journal of Chromatography B 2008; 873: 144-150.

13. Yamanouchi T, Akanuma H, Nakamura T, Akaoka I, and Akanuma Y. Reduction of plasma 1,5-anhydroglucitol (1-deoxyglucose) concentration in diabetic patients. Diabetologia 1988; 31: 41-45.

14. Wright LA, Hirsch IB. The challenge of the use of glycemic biomarkers in diabetes: Reflecting on hemoglobin A1C, 1,5-anhydroglucitol, and the glycated proteins fructosamine and glycated albumin. Diabetes Spectrum 2012; 25: 141-148.

15. Stettler C, Stahl M, Allemann S, Diem P, Scmidlin K, Zwahlen M, et al. Association of 1,5-anhydroglucitol and 2-h postprandial blood glucose in type 2 diabetic patients. Diabetes Care 2008; 31: 1534-1535.

16. Mehta SN, Schwartz N, Wood JR, Svoren BM, Laffel LM. Evolution of 1,5anhydroglucitol hemoglobin A1c, and glucose levels in youth and young adults with type 2 diabetes and healthy controls. Pediatric Diabetes 2011; 13: 278-284.

17. Dungan KM, Buse JB, Largay J, Kelly MM, Button EA, Kato S, et al. 1,5-anhydro-glucitol and postprandial hyperglycemia as measured by continuous glucose monitoring system in moderately controlled patients with diabetes. Diabetes Care 2006; 29: 1214-1219.

18. Baker JR, O'Connor JP, Metcalf PA, Lawson MR, Johnson RN. Clinical usefulness of estimation of serum fructosamine concentration as a screening test for diabetes mellitus. BMJ 1983; 287: 863-867.

19. Shaw JE, Sicree RA, Zimmet PZ. Global estimates of the prevalence of diabetes for 2010 and 2030. Diabetes Research and Clinical Practice 2010; 87: 4- 14.

20. The International Expert Committee. International Expert Committee report on the role of the A1C assay in the diagnosis of diabetes. Diabetes Care 2009; 32: 1327-1334.

21. Nguyen TT, Wang JJ, Wong TY. Retinal vascular changes in pre-diabetes and prehypertension : new findings and their research and clinical implications. Diabetes Care 2007; 30:2708-2715. 
Thi-Qar Medical Journal (TQMJ): Vol.(19), No.(1), 2020

Web Site: https://jmed.utq.edu.iq

\section{ISSN (Print):1992-92 18, ISSN (Online):1992-92 18 \\ DOI: https://doi.org/10.32792/utq/utjmed/19/1/10}

Email:utjmed@utq.edu.iq

22. Diabetes Prevention Program Research Group. The prevalence of retinopathy in impaired glucose tolerance and recent-onset diabetes in the diabetes prevention program. Diabetes Medicine 2007; 24:137-144.

23. Sumner CJ, Sheth S, Griffin JW, Cornblath DR, Polydefkis M. The spectrum of neuropathy in diabetes and impaired glucose tolerance. Neurology. 2003; 60:108-111.

24. Herman WH. Diabetes epidemiology: guiding clinical and public health practice: the Kelly West Award Lecture, 2006. Diabetes Care 2007; 30:1912-1919.

25. Barr ELM, Zimmet PZ, Welborn TA, Jolley D, Magliano DJ, Dunstan DW. Risk of cardiovascular and all-cause mortality in individuals with diabetes mellitus, impaired fasting glucose and impaired glucose tolerance. The Australian Diabetes 2007; 116: 1-7.

26. Wang Y, Zhang YL, Wang YP, Lei CH, Sun ZL.A study on the association of serum 1,5anhydroglucitol levels and the hyperglycaemic excursions as measured by continuous glucose monitoring system among people with type 2 diabetes in China. Diabetes / Metabolism Research and Reviews 2012; 28: 357-362.

27. Hanefeld M, Fischer S, Julius U, Schulze J, Schwanebeck U, Schmechel H, et al. Risk factors for myocardial infarction and death in newly detected NIDDM: The Diabetes Intervention Study, 11-year follow up. Diabetologia 1996; 39: 1577 -1583.

28. Muggeo M, Zoppini G, Bonora E, Brun E, Bonadonna RC, Moghetti P, et al. Fasting plasma glucose variability predicts 10 -year survival of type 2 diabetic patients: the Verona Diabetes Study. Diabetes Care 2000; 23: 45 -50.

29. Home P. The challenge of poorly controlled diabetes mellitus. Diabetes Metabolism 2003; 29: 101-109.

30. Sarah W, Gojka R, Anders G, Richard S, Hilary K. Global prevalence of diabetes. Diabetes care 2004; 27: 1047-1053.

31. Gopinath B, Srisaiprasad M, Jayarama N, Prabhakara K. Study of factors associated with poor glycemic control in type -2 diabetic patients. Global Journal of Medicine and Public Health. 2013; 2: 1-5.

32. Taha JY, Ajlan SK, Abdul-Salam M. Haemoglobinopathies and glycated haemoglobin: Influence in non-diabetic and diabetic patients. Journal of the Bahrain Medical Society 2005; $17: 111$ - 114. 
Thi-Qar Medical Journal (TQMJ): Vol.(19), No.(1), 2020

Web Site: https://jmed.utq.edu.iq

Email:utjmed@utq.edu.iq

\section{ISSN (Print):1992-92 18, ISSN (Online):1992-92 18 \\ DOI: https://doi.org/10.32792/utq/utjmed/19/1/10}

33. Al-Naama LM, Ajlan SK, Mahmood MS. Evaluation of lipid and lipoprotein profile in patients with insulin dependent diabetes mellitus. Journal of the Bahrain Medical Society. 2009; $21: 298-301$.

34. Al-Naama LM, Ajlan SK, Mahmood MS. Evaluation of Lipid and Lipoprotein Profile in Patients with Type 2 Diabetes. The Medical Journal of Basrah University 2010; 27: 27-32.

35. Al-Naama LM, Ajlan SK, Mahmood MS. Glycaemic control in diabetes mellitus. Thi-Qar Med J 2011; 5: 25-29.

36. Mansour AA. Type II diabetes mellitus: presentations, complications and treatment. The Medical Journal of Basrah University 2002, 20: 41-48.

37. Ajlan SK, Abdulkader AA, Mijbil AY, The impact of metabolic syndrome in type 2 diabetic patients. The Medical journal of Basrah University 2012; 30: 85-90.

38. Herman WH, Dungan KM, Wolffenbuttel BHR, Buse JB, Fahrbach JL, Jiang H, et al. Racial and ethnic differences in mean plasma glucose, hemoglobin A1c, and 1,5anhydroglucitol in over 2000 patients with type 2 diabetes. Journal of Clinical Endocrinology and Metabolism. 2009: 94: 1689-1694.

39. Pal A, Farmer AJ, Dudley C, Selwood MP, Barrow BA, Klyne R. Evaluation of serum 1,5anhydroglucitol levels as a clinical test to differentiate subtypes of diabetes. Diabetes Care 2010; 33: 252-257.

40. Yamanouchi T, Ogata N, Tagaya T, Kawasaki T, Sekino N, Funato H, et al. Clinical usefulness of serum 1,5-anhydroglucitol in monitoring glycaemic control. Lancet 1996; 347:1514-1518.

41. Lu CC, Lam HC, Chu CH, Chaung MJ, Wang MC, Lee JK. 1,5-anhydroglucitol levels in type 2 diabetic and non-diabetic subjects in Southern Taiwan. Arquivos Brasileiros de Endocrinologia \& Metabologia 2003; 47: 711 - 715.

42. Moses AC, Raskin P, Khutoryansky N. Does Serum 1,5-anhydroglucitol establish a relationship between improvement in HbA1c and postprandial glucose excursions? Supportive evidence utilizing the differential effects between biphasic insulin aspart 30 and insulin glargine. Diabetes Medicine 2008; 25:200-205.

43. Pramodkumar TA, Jayashri R, Gokulakrishnan K, Velmurugan K, Pradeepa R, Anjana $\mathrm{RM}$, et al. Relationship of glycemic control markers, 1,5-anhydroglucitol, fructosamine, and 
Thi-Qar Medical Journal (TQMJ): Vol.(19), No.(1), 2020

Web Site: https://jmed.utq.edu.iq

Email:utjmed@utq.edu.iq

ISSN (Print):1992-92 18, ISSN (Online):1992-92 18

DOI: https://doi.org/10.32792/utq/utjmed/19/1/10

glycated hemoglobin among Asian Indians with different degrees of glucose intolerance. Journal of Endocrinology and Metabolism 2016; 20: 690-695.

44. Suzuki SH, Koga M. Glycemic control indicators in patients with neonatal diabetes mellitus. World Journal of Diabetes 2014; 5: 198-208.

45. Wang Y, Yuan Y, Zhang Y, Lei C, Zhou Y, He J, et al. Serum 1,5-anhydroglucitol level as a screening tool for diabetes mellitus in a community-based population at high risk of diabetes. Acta Diabetologica 2017; 54: 425-431.

46. Ying L, He X, Ma X, Shen Y, Su H, Peng J, et al. Serum 1,5-anhydroglucitol when used with fasting plasma glucose improves the efficiency of diabetes screening in a Chinese population. Scientific Reports 2017; 7: 1-8.

47. Halama A, Kulinski M, Abdul Kader S, Satheesh NJ, Abou-Samra A, Suhre K, et al. Measurement of 1,5-anhydroglucitol in blood and saliva: from non- targeted metabolomics to biochemical assay. Journal of Translational Medicine. 2016; 14: 140-149.

48. Koga M. 1,5-anhydroglucitol and glycated albumin in glycemia. Advance Clinical Chemistry. 2014; 64 : 269-301.

49. Sun J, Dou JT, Wang XL, Yang GQ, Lu ZH, Zheng H. Correlation between 1,5anhydroglucitol and glycemic excursions in type 2 diabetic patients. Chinese Medical Journal 2011; 124: 3641-3645.

50. Kim WJ, Park CY. 1,5-anhydroglucitol in diabetes mellitus. Endocrine 2013; 43: 33-40.

51. Sato A. [Indicators of glycemic control-hemoglobin A1c (HbA1c), glycated albumin (GA), and 1,5-anhydroglucitol (1,5-AG)]. Ransho Byori (The Japanese Journal of Clinical Pathology) 2014; 62: 45-52.

52. Kim MJ, Jung HS, Hwang-Bo Y, Cho SW, Jang HC, Kim SY, et al. Evaluation of 1,5-anhydroglucitol as a marker for glycemic variability in patients with type 2 diabetes mellitus. Acta Diabetologia. 2013; 50: 505-510.

53. Beck R, Steffes M, Xing D, Ruedy K, Mauras N, Wilson DM, et al. The interrelationships of glycemic control measures: HbA1c, glycated albumin, fructosamine, 1,5-anhydroglucitrol, and continuous glucose monitoring. National Institute of Health Public Access 2011; 12: 690695. 
Thi-Qar Medical Journal (TQMJ): Vol.(19), No.(1), 2020

Web Site: https://jmed.utq.edu.iq

Email:utjmed@utq.edu.iq

ISSN (Print):1992-92 18, ISSN (Online):1992-92 18

DOI: https://doi.org/10.32792/utq/utjmed/19/1/10

54. Kinnaird KE, Sauerwein TJ. Lack of correlation between 1,5-anhydroglucitol assay and oral glucose tolerance test in patients with cystic fibrosis. Endocrinology Practice 2010; 16: 167-170.

55. Januszewski AS, Karschimkus C, Davis KE, O'Neal D, Ward G, Jenkins AJ. Plasma 1,5anhydroglucitol levels, a measure of short- term glycemia: assay assessment and lower levels in diabetic vs. non-diabetic subjects. Diabetes Research and Clinical Practice. 2012; 95: 17-19.

Table 1. Socio- demographic characteristics of diabetic patients.

\begin{tabular}{|c|c|c|c|}
\hline \multicolumn{2}{|c|}{ Characteristic } & No. & $\%$ \\
\hline \multirow{3}{*}{ Age (years) } & $25-44$ & 11 & 14.5 \\
\hline & $45-64$ & 57 & 75 \\
\hline & $\geq 65$ & 8 & 10.5 \\
\hline \multirow[t]{2}{*}{ Gender } & Males & 33 & 43.4 \\
\hline & Females & 43 & 56.6 \\
\hline \multirow[t]{2}{*}{ Residency } & Urban & 55 & 72.4 \\
\hline & Rural & 21 & 27.6 \\
\hline \multirow[t]{2}{*}{ Educational } & Illiterate & 15 & 19.7 \\
\hline & Just read and write & 2 & 2.6 \\
\hline \multirow[t]{2}{*}{ Level } & Primary school & 40 & 52.6 \\
\hline & Secondary school and more & 19 & 25 \\
\hline \multirow[t]{3}{*}{ Smoking habit } & Non-Smoker & 63 & 82.9 \\
\hline & Current-Smoker & 10 & 13.2 \\
\hline & Ex-Smoker & 3 & 3.9 \\
\hline
\end{tabular}


Thi-Qar Medical Journal (TQMJ): Vol.(19), No.(1), 2020

Web Site: https://jmed.utq.edu.iq

ISSN (Print):1992-92 18, ISSN (Online):1992-92 18

DOI: https://doi.org/10.32792/utq/utjmed/19/1/10
Email:utjmed@utq.edu.iq

Table 2. Clinical characteristics of diabetic patients.

\begin{tabular}{|c|c|c|c|c|c|}
\hline \multicolumn{3}{|c|}{ Characteristic } & No. & $\%$ & Mean \pm SD \\
\hline \multirow{4}{*}{$\begin{array}{c}\text { BP } \\
(\mathrm{mm} . \mathrm{Hg})\end{array}$} & \multicolumn{2}{|c|}{ SBP ( males ) } & & & $134.7 \pm 23.2$ \\
\hline & \multicolumn{2}{|c|}{ DBP (males ) } & & & $84.39 \pm 7.8$ \\
\hline & \multicolumn{2}{|c|}{ SBP (females ) } & & & $136.7 \pm 19.4$ \\
\hline & \multicolumn{2}{|c|}{ DBP (females ) } & & & $86.0 \pm 9.0$ \\
\hline BMI ( Kg/m²) & \multicolumn{2}{|c|}{ Overall } & & & $30.9 \pm 4.9$ \\
\hline \multirow[t]{5}{*}{ BMI groups } & \multicolumn{2}{|c|}{$\begin{array}{c}\text { Normal range } \\
18.5-25\end{array}$} & 6 & 7.9 & \\
\hline & \multicolumn{2}{|c|}{$\begin{array}{l}\text { Over weight } \\
25-30\end{array}$} & 26 & 34.2 & \\
\hline & \multicolumn{2}{|c|}{$\begin{array}{c}\text { Grade I obesity } \\
\text { 30- } 35\end{array}$} & 28 & 36.8 & \\
\hline & \multicolumn{2}{|c|}{$\begin{array}{l}\text { Grade II obesity } \\
35-40\end{array}$} & 13 & 17.1 & \\
\hline & \multicolumn{2}{|c|}{$\begin{array}{l}\text { Grade III obesity } \\
\quad \geq 40\end{array}$} & 3 & 3.9 & \\
\hline \multirow{4}{*}{$\begin{array}{l}\text { WC } \\
(\mathbf{c m})\end{array}$} & \multirow[t]{2}{*}{ Males } & $<102$ & 10 & 30.3 & \multirow[t]{2}{*}{$104.9 \pm 13.4$} \\
\hline & & $\geq 102$ & 23 & 69.7 & \\
\hline & \multirow[t]{2}{*}{ Females } & $<88$ & 2 & 4.7 & \multirow[t]{2}{*}{$107.2 \pm 15.1$} \\
\hline & & $\geq 88$ & 41 & 95.3 & \\
\hline \multirow{3}{*}{$\begin{array}{c}\text { Duration of DM } \\
\text { (years) }\end{array}$} & & & 22 & 28.9 & \multirow[t]{3}{*}{$9.4 \pm 5.5$} \\
\hline & & & 37 & 48.6 & \\
\hline & & & 17 & 22.4 & \\
\hline \multirow{3}{*}{$\begin{array}{l}\text { Treatment } \\
\text { modality }\end{array}$} & & & 24 & 31.6 & \\
\hline & & & 27 & 35.5 & \\
\hline & Both in & ind OHA & 25 & 32.9 & \\
\hline
\end{tabular}


Thi-Qar Medical Journal (TQMJ): Vol.(19), No.(1), 2020

Web Site: https://jmed.utq.edu.iq

Email:utjmed@utq.edu.iq

ISSN (Print):1992-92 18, ISSN (Online):1992-92 18

DOI: https://doi.org/10.32792/utq/utjmed/19/1/10

Table 3. Biochemical characteristics of diabetic patients.

\begin{tabular}{|r|c|c|c|c|c|}
\hline \multicolumn{2}{|c|}{ Parameter } & No. & $\%$ & Mean \pm SD & Range \\
\hline \multirow{2}{*}{ FBG (mg/dl) } & $100-125.9$ & 6 & 7.9 & $235.33 \pm 81.14$ & $100-406.8$ \\
\cline { 2 - 5 } & $\geq 126$ & 70 & 92.1 & & \\
\hline HbA1c (\%) & $<7$ & 2 & 2.6 & $10.47 \pm 1.96$ & $6.6-15.3$ \\
\hline & $7-7.9$ & 5 & 6.6 & & \\
\hline & $\geq 8$ & 69 & 90.8 & & \\
\hline & $\mathbf{1 , 5 - A G}(\boldsymbol{\mu g} / \mathbf{m l})$ & 76 & 100 & $3.62 \pm 1.56$ & $0.15-7.7$ \\
\hline
\end{tabular}

Table 4. Status of glycemic control and serum 1,5-AG levelsamong diabetic patients.

\begin{tabular}{|c|c|c|c|c|c|}
\hline $\begin{array}{l}\text { Glycemic } \\
\text { status }\end{array}$ & HbA1c $(\%)$ & No. & $\%$ & $\begin{array}{l}1,5-A G \\
(\mu \mathrm{g} / \mathrm{ml})\end{array}$ & P-value \\
\hline $\begin{array}{l}\text { Optimal } \\
\text { control }\end{array}$ & $<7.0$ & 2 & 2.6 & $5.04 \pm 2.47 *$ & 0.271 \\
\hline $\begin{array}{l}\text { Acceptable } \\
\text { control }\end{array}$ & $7.0-8.0$ & 5 & 6.6 & $2.94 \pm 1.49 *$ & \\
\hline $\begin{array}{c}\text { Poor } \\
\text { control }\end{array}$ & $\geq 8.0$ & 69 & 90.8 & $3.63 \pm 1.53 *$ & \\
\hline Total & Total & 76 & 100.0 & $3.62 \pm 1.56^{*}$ & \\
\hline
\end{tabular}


Thi-Qar Medical Journal (TQMJ): Vol.(19), No.(1), 2020

Web Site: https://jmed.utq.edu.iq

Email:utjmed@utq.edu.iq

ISSN (Print):1992-92 18, ISSN (Online):1992-92 18

DOI: https://doi.org/10.32792/utq/utjmed/19/1/10

تقييم مستويات ه، 1 انهايلرو كلوسيتول عند مرضى السكري من التوع الثاني

كلية الصيالة - جامعة البصرة

فرع الكيمياء العياتية، كلية الطب \جامعة البصرة ـ البصرة) العراق الصعرة

صفا كماح قُاسم

سلمان كاظم عجلان

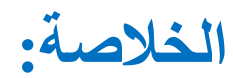

الهُف: در اسة مستويات 0، 1 انهايدروكلوسيتول عند مرضى السكري من النوع r.

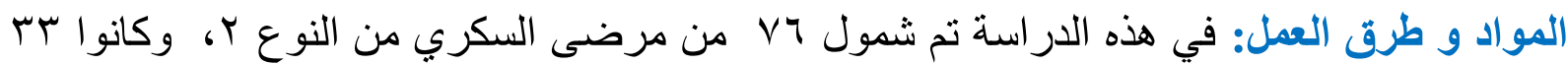

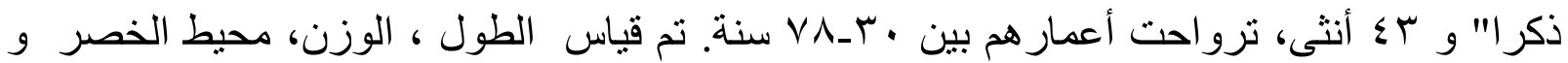
ضغط الدم ـ تم تحديد مستويات سكر الدم، خضاب الدم السكري و 0، 1 انهايدروكلوسيتول في الدم.

النتائج: أظهرت الدراسة انخفاض مستويات 0، 1 انهايدروكلوسيتول عند مرضى السكري من النوع

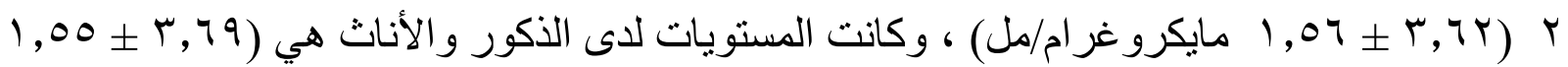

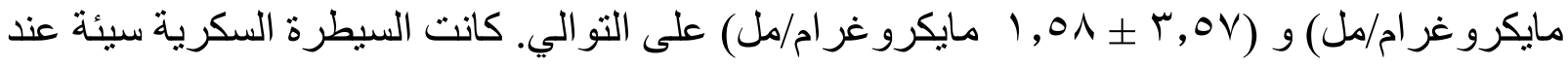
الغالبية العظمى من المرضى (^, •9\% )، بينما كانت السيطرة السكرية مقبولة عند (؟, ؟\%\%) من المرضى ، وكانت مثالية عند (؟, ؟\%\%) فقط من المرضى. لم تكن هناللك أختلافات معنوية في مستويات 0، 1 انهايدروكلوسيتول حسب درجة السيطرة السكرية (ب > 0 . . •).

الأستنتاجات : كانت مستويات 0، 1 انهايدروكلوسيتول منخفضة عند مرضى السكري من النوع ب ، مما قد يشير الى دور محتمل له في تشخيص مرض السكري. كانت السيطرة السكرية سيئة عند المرضى مما يجعلهم و بشكل كبير أكثر عرضة للأصابة بالمضاعفات المتعددة للمرض.

مفاتيح الكلمات: مرض السكري، مستوى 0، 1 انهايدروكلوسيتول ، السيطرة الأيضية. 